\title{
De waarde van Audit Quality Indicators bij de rol van de auditcommissie in relatie tot de accountant
}

\author{
Auke de Bos, Martijn de Jong
}

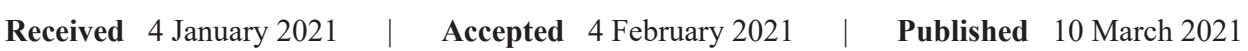

\section{Samenvatting}

Audit Quality Indicators (AQI's) kunnen een ondersteunende rol bieden bij het beoordelen van en sturen op de kwaliteit van de wettelijke controle (hierna: controlekwaliteit). Dit artikel geeft invulling aan AQI's voor gebruik door auditcommissies. Hiervoor is gebruik gemaakt van een bestaande Canadese set aan AQI's die zijn toegepast op de Nederlandse verantwoordelijkheden van auditcommissies. Waar nodig zijn de AQI's uitgebreid en aangepast. Er is nog weinig onderzoek gedaan naar de toegevoegde waarde van AQI's voor de auditcommissie.

Voorlopig kan geconcludeerd worden dat AQI's voor auditcommissies meer ondersteunend zijn dan cruciaal. De AQI's vergroten de informatievoorziening naar de auditcommissie voor het uitvoeren van hun taken en het nemen van beslissingen ten aanzien van de accountant, maar lijken (nog) geen alomvattend wondermiddel. Het advies is om auditcommissies in het verslag van de raad van commissarissen melding te laten maken van de mate van gebruik van AQI's. Door deze informatie met alle belanghebbenden te delen wordt de kennis en waarde van AQI's breder bekend en gedeeld.

De conclusies op basis van de AQI's kunnen samen met de andere elementen een rol spelen bij het evalueren van het functioneren van de accountant en het sturen op de controlekwaliteit. Ten slotte is duidelijk dat (nog) niet voor iedere rol/taak van de auditcommissie geschikte AQI's beschikbaar zijn.

\section{Relevantie voor de praktijk}

Door de ontwikkelingen in en rondom het accountantsberoep staat de kwaliteit van de wettelijke controle in de schijnwerpers. Auditcommissies spelen bij het borgen van de kwaliteit ook een rol. AQI's kunnen een ondersteunende rol bieden bij het beoordelen van en sturen op controlekwaliteit. Dit is een aanzet voor auditcommissies om AQI's meer en beter te gebruiken en biedt daartoe analyses en praktische handvatten.

\section{Trefwoorden}

audit quality indicators, audit quality, auditcommissie, corporate governance, accountant, controlekwaliteit, raad van commissarissen

\section{Inleiding}

De afgelopen jaren is veel gesproken en geschreven over nut en noodzaak van 'objectieve' standaard-kwaliteitsindicatoren voor de accountantscontrole, de zogenaamde Audit Quality Indicators (AQI's). Het rapport van de Commissie Toekomst Accountancysector (CTA 2020)

stelt dat "een juist en integraal beeld van de kwaliteit van wettelijke controles op verschillende niveaus, op basis van eenduidige standaarden (indicatoren) ontbreekt". "Om de kwaliteit van de wettelijke controles beter inzichtelijk te maken en de komende jaren te toetsen dienen op 
korte termijn AQI's voor alle relevante niveaus te worden vastgesteld. Deze moeten eenduidig zijn, (centraal) publiek beschikbaar en gecontroleerd door de toezichthouder". In de tweede helft van 2020 hebben de kwartiermakers Toekomst Accountancysector de aftrap gegeven voor de werkgroepen die moeten bijdragen aan de totstandkoming van AQI's. Voor meerdere partijen in de keten, waaronder de auditcommissie kunnen AQI's toegevoegde waarde hebben.

Auditcommissies ${ }^{1}$ hebben verantwoordelijkheden ten aanzien van de aanstelling en het beoordelen van het functioneren van de accountant. De toegevoegde waarde van AQI's voor auditcommissies in het vervullen van deze rol lijkt onmiskenbaar. Dit artikel verkent, mede op basis van een Canadese publicatie over AQI's voor auditcommissie, welke AQI's relevant en bruikbaar zijn voor gebruik door auditcommissies in Nederland en bevat praktische aandachtspunten voor (de start van) het gebruik van AQI's.

Allereerst gaat dit artikel in sectie 2 beknopt in op het theoretisch kader aan de hand van de corporate governance driehoek. Vervolgens wordt de praktijkhandreiking "publicatie kwaliteitsfactoren" besproken. Daarna, in sectie 3, gaat het artikel in op AQI's, de ontwikkeling hiervan, de externe toezichthouder en de waarde van AQI's bij de rol van de auditcommissies in relatie tot de accountant. Afsluitend bevat sectie 4 de conclusies en praktische aandachtspunten voor de auditcommissie bij het opstellen en gebruiken van AQI's.

\section{Rol van de auditcommissie}

\subsection{Theoretisch kader}

Om de rol van de accountant en de raad van commissarissen/auditcommissie goed te kunnen duiden, biedt het model in figuur 1 een bruikbaar handvat (De Bos et al. 2016).

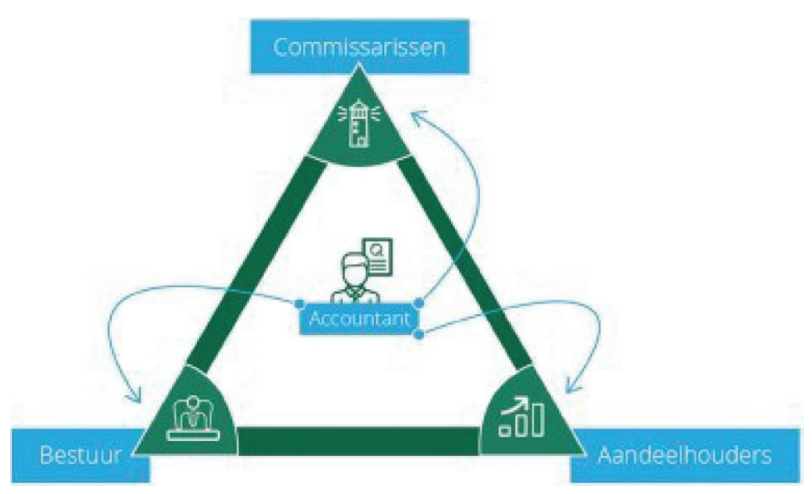

Figuur 1. De corporate governance-driehoek.

Bij organisaties waar bestuurders, commissarissen en aandeelhouders zijn betrokken, geven de aandeelhouders een mandaat aan bestuurders en stellen zij commissarissen aan om toe te zien op diezelfde bestuurders. De accountant heeft een steeds belangrijker rol in relatie tot deze drie partijen. Het toezicht op de financiën is gedelegeerd aan commissarissen, die accountants 'inhuren' om onderzoek te doen naar de jaarrekening. Na een aanbeveling van de auditcommissie (als subcommissie van de raad van commissarissen) stelt de algemene vergadering van aandeelhouders de accountant aan. De commissarissen moeten met behulp van de auditcommissie hun visie willen geven op het controleplan, de belangrijkste bevindingen van de controle en de controleverklaring, inclusief de kernpunten van de controle ('Key Audit Matters'). De commissarissen evalueren tot slot het functioneren van de accountant, een belangrijke voorwaarde voor het monitoren van de onafhankelijkheid van de accountant. Op verschillende momenten in dit proces kunnen AQI's ondersteuning bieden.

\subsection{NBA Praktijkhandreiking "publicatie kwaliteits- factoren"}

De Nederlandse Beroepsorganisatie van Accountants ('NBA') heeft in 2016 de praktijkhandreiking "publicatie kwaliteitsfactoren" uitgebracht. Deze handreiking is van toepassing op accountantsorganisaties met een OOB-vergunning en ziet toe op het toelichten van kwaliteitsfactoren in het transparantieverslag. In de praktijkhandreiking is opgenomen dat een accountantsorganisatie, om te voldoen aan de kwaliteitsambitie, een aantal meetbare doelstellingen zal hebben geformuleerd ten aanzien van de maatregelen (input) ter verbetering van de kwaliteit, de kwaliteitswaarborgen binnen het proces van uitvoering van de controle (proces) en de gewenste uitkomsten (output).

Om haar prestaties en voortgang bij het realiseren van haar kwaliteitsambitie, en de op grond daarvan geformuleerde doelstellingen, te meten zal de organisatie een aantal kwaliteitsfactoren hebben geïdentificeerd die voor haar maatgevend zijn - de KPI's op het gebied van kwaliteit. Deze procesmatige indeling uit 2016 is de eerste aanzet geweest voor de ontwikkeling en het gebruik van AQI's in Nederland en vormt de basis voor de genoemde transparantieverslagen.

\section{AQI's in ontwikkeling en relevantie voor de auditcommissie}

\subsection{Wat is een AQI?}

Zoals Majoor (2016) beschreef zijn Quality indicators 'hot' in accountancyland en staan ze hoog op de agenda van wetenschappers, regelgevers en accountantsorganisaties. Het idee is om AQI's te ontwikkelen en daarmee controlekwaliteit beter te begrijpen (Majoor 2016). Immers controlekwaliteit is een moeilijk in te kaderen begrip. Naast de output, de controleverklaring, is ook het proces een onderdeel van controlekwaliteit. Gebruikers hebben juist in deze onderdelen een beperkt inzicht. Er is sprake van een kenniskloof tussen gebruikers van het 


\begin{tabular}{|c|c|c|c|c|c|c|c|c|c|c|}
\hline Issuing body & NBA & FAOA & $\begin{array}{l}\text { FRC } \\
\text { UK }\end{array}$ & PCAOB & $\begin{array}{l}\text { US } \\
\text { CAQ }\end{array}$ & CPAB & CAANZ & ACRA & $105 c 0$ & Tota \\
\hline $\begin{array}{l}\text { 1. Training hours per audit } \\
\text { personnel }\end{array}$ & $x$ & & $\mathrm{x}$ & $\mathrm{x}$ & $x^{*}$ & $x$ & $\mathrm{x}^{*}$ & $\mathbf{x}$ & $x^{*}$ & 8 \\
\hline $\begin{array}{l}\text { 2. 'Internal engagement } \\
\text { quality views' }\end{array}$ & $x$ & $x^{4}$ & $\mathrm{x}$ & $x$ & $\mathrm{x}$ & & & $x$ & & 6 \\
\hline 3. External inspections & $x$ & & $\mathrm{x}$ & $\mathrm{x}$ & $x$ & & & $\mathrm{x}$ & $\mathrm{x}$ & 6 \\
\hline $\begin{array}{l}\text { 4. Number of audit staff } \\
\text { per audit partner }\end{array}$ & & $x$ & & $x$ & & $x$ & $x^{*}$ & $x$ & & 5 \\
\hline 5. Years of experience & & & & $x$ & $x$ & $x$ & & $x$ & $x$ & 5 \\
\hline 6. Partner workload & $x^{5}$ & & & $x$ & $x$ & $x$ & & $x$ & & 5 \\
\hline $\begin{array}{l}\text { 7. Industry expertise of } \\
\text { audit personnel }\end{array}$ & & & & $x$ & $x$ & $x$ & & $\mathrm{x}$ & $\mathrm{x}$ & 5 \\
\hline 8. Staff workload & & & & $x$ & $x$ & $x$ & & & $x$ & 4 \\
\hline $\begin{array}{l}\text { 9. Investment in } \\
\text { development of new } \\
\text { audit methodology and } \\
\text { tools }\end{array}$ & $x$ & & $x$ & $x$ & & & $\mathrm{x}$ & & & 4 \\
\hline 10. Staff turnover & $x$ & $x$ & & $x$ & & & & $x$ & & 4 \\
\hline 11. Independence & $x$ & & & $x$ & & & & $x$ & $x$ & 4 \\
\hline $\begin{array}{l}\text { 12. Technical resources } \\
\text { support }\end{array}$ & $x$ & & & $x$ & $x$ & $x$ & & & & 4 \\
\hline 13. Staff satisfaction survey & $x^{6}$ & & $\mathrm{x}$ & $x$ & & & & & & 3 \\
\hline 14. External investigations & $x$ & & $\mathrm{x}$ & $x$ & & & & & & 3 \\
\hline 15. Tone at the top & & & & $\mathrm{x}$ & $x$ & & & & $x$ & 3 \\
\hline
\end{tabular}

bron: Reporting by Audit Oversiight Bodies - Centre for Financial Reporting Reform

Figuur 2. World Bank 2018.

product controleverklaring en de aanbieders daarvan. Er lijkt daarmee een behoefte om controlekwaliteit beter te begrijpen en een gemeenschappelijke visie en inzicht te creëren in factoren die van invloed zijn op controlekwaliteit. In het verlengde daarvan is er ook de behoefte van accountantsorganisaties om controlekwaliteit met behulp van AQI's te sturen en te beheersen. Met indicatoren kan dit begrip inzichtelijk worden gemaakt en daarmee stuurbaar. Een omschrijving van een indicator die in het ketenmanagement veel wordt gebruikt is de volgende: "Een indicator is een meetbaar fenomeen dat een signalerende functie heeft en een aanwijzing geeft over de mate van kwaliteit. Wijkt een indicator af van een afgesproken norm dan is bijsturing mogelijk".

In een rapport van de World Bank (2018, p. 18) wordt de volgende definitie van AQI gebruikt - "Audit quality indicators (AQIS) refers to a set of indicators designed to measure audit quality and provide a basis for comparison across different audits and audit firms. AQIs seek to increase transparency around the audit process also provide a means for audit committees and $A O B$ 's to gauge the quality of audits and provide valuable and pertinent information for their activities."

Er zijn internationaal diverse initiatieven gestart met als doel om met behulp van AQI's de dialoog met stakeholders over controlekwaliteit te stimuleren. In 2020 heeft dit in Nederland dus een vervolg gekregen door het instellen van AQI-werkgroepen door de Kwartiermakers Toekomst Accountancysector.

\subsection{Ontwikkeling van AQI's}

Zoals in de inleiding weergegeven ziet het CTA-rapport (2020) een belangrijke rol voor AQI's: “Om de kwaliteit van de wettelijke controles beter inzichtelijk te maken en de komende jaren te toetsen, dienen op korte termijn AQI's voor alle relevante niveaus te worden vastgesteld. Deze moeten eenduidig zijn, (centraal) publiek beschikbaar en beoordeeld door de toezichthouder."

De ontwikkeling van AQI's en het nut en de noodzaak ervan zijn hot topics. Indicatoren zullen, vergelijkbaar met KPI's vrijwel altijd maatwerk zijn. Ten aanzien van de (internationale) ontwikkeling van AQI's verwijst de CTA naar:

- het project Audit Quality Indicators van de PCAOB (2019) waarbij de Amerikaanse toezichthouder 28 potentiële indicatoren identificeert in de categorieën audit professionals, audit process en audit results (Pinello et al. 2019);

- het rapport van onder meer de Canadese toezichthouder, de Canadian Public Accounting Board, (CPAB 2018) dat ten behoeve van auditcommissies circa 20 potentiële indicatoren identificeert; en

- het rapport van de Wereldbank uit 2018 Reporting by Audit Oversight Bodies dat een overzicht bevat van door diverse toezichthouders geformuleerde en gehanteerde AQI's.

Figuur 2 geeft een overzicht van de door diverse toezichthouder geformuleerde en gehanteerde AQI's. Dit betreffen 'algemene' AQI's, niet specifiek voor de auditcommissie. Dat wil niet zeggen dat deze in de desbetreffende landen gemeengoed zijn en veelvuldig worden gebruikt. Met name in Noord-Amerika is de ontwikkeling en het gebruik van AQI's verder dan in Nederland. De rol van de accountant verschilt niet significant tussen dat continent en de West-Europese. Het is daarom goed om gebruik te maken van daar ontwikkelde 'thought leadership', guidance en te leren van opgedane ervaringen. 


\subsection{Externe toezichthouders en AQI's}

Externe toezichthouders zijn in toenemende mate geïnteresseerd in de rol en effectiviteit van auditcommissies. In de EU is een 'monitoring capacity' ingevoerd. Dit betekent dat toezichthouders de ontwikkelingen in de accountancymarkt monitoren door - onder andere - het beoordelen van het functioneren van de auditcommissie ten aanzien van de externe accountant. De EU audit reform (Euopean Parliament 2014) vereist dat de EU 'competent authorities' (toezichthouders waar onder andere de AFM en mededingingsautoriteiten onderdeel van uitmaken) het functioneren van de auditcommissies van OOB's gaan beoordelen en hierover vanaf 2016 driejaarlijks rapporteren.

Ook de AFM (2020) ziet dat auditcommissies een belangrijke schakel zijn in de keten van partijen die voor goede verslaggeving en wettelijke controles moeten zorgen. Auditcommissies geven de raad van commissarissen advies over de voordracht van de externe accountant en monitoren de wettelijke controle van de jaarrekening door de accountantsorganisatie. De AFM wil in dat kader graag weten hoe de auditcommissies hun verantwoordelijkheid hierin nemen. Dat past binnen de steeds belangrijker wordende rol van de auditcommissie. Auditcommissies kunnen een belangrijke rol spelen bij de verbetering van de kwaliteit van de wettelijke controles en jaarverslaggeving. De AFM is dan ook geïnteresseerd in hoe auditcommissies hun verantwoordelijkheden uitvoeren en voerde daartoe in 2020 een verkennend onderzoek uit. Ook het Nationaal Commissarissen-onderzoek van De Bos en Lückerath (2014) heeft eerder uitgebreid aandacht gehad voor de toegevoegde waarde van de accountant.

In maart 2015 publiceerde de AFM het rapport auditcommissies "Verkenning naar kritisch vermogen auditcommissies bij verslaggeving en accountantscontrole". Ook vanuit de toezichthouder is er behoefte aan objectieve criteria. De AQI's kunnen daarbij een rol spelen.

\subsection{De waarde van Audit Quality Indicators bij de rol van de auditcommissie in relatie tot de accountant}

Het CTA-rapport stelt dat "een juist en integraal beeld van de kwaliteit van wettelijke controles op verschillende niveaus, op basis van eenduidige standaarden (indicatoren) ontbreekt".

"Om de kwaliteit van de wettelijke controles beter inzichtelijk te maken en de komende jaren te toetsen dienen op korte termijn AQI's voor alle relevante niveaus te worden vastgesteld. Deze moeten eenduidig zijn, (centraal) publiek beschikbaar en gecontroleerd door de toezichthouder", aldus de CTA. In de tweede helft van 2020 hebben de kwartiermakers Toekomst Accountancysector de aftrap gegeven voor de werkgroepen die moeten bijdragen aan de totstandkoming van AQI's. Voor meerdere partijen in de keten, waaronder de auditcommissie kunnen AQI's toegevoegde waarde hebben. Auditcommissies hebben verantwoordelijkheden ten aanzien van de aanstelling en het beoordelen van het functioneren van de accountant. De toegevoegde waarde van AQI's voor auditcommissies in het vervullen van deze rol lijkt onmiskenbaar. Het is van belang dat de auditcommissie in haar toezichthoudende rol zich een oordeel kan vormen over het functioneren van de externe accountant en het beoordelen van de controlekwaliteit. Er komt internationaal meer nadruk op het meten van controlekwaliteit door de ontwikkeling van AQI's door toezichthouders, beroepsorganisaties en accountantsorganisaties (Federation of European Accountants 2015). Deze indicatoren kunnen auditcommissies ondersteunen bij het meer objectief evalueren van het functioneren van de accountant ten aanzien van controlekwaliteit. Hierbij is het selectieproces van de juiste AQI's van groot belang en moet worden onderkend dat subjectieve factoren ook een rol spelen.

Een voorbeeld van het inzichtelijk maken van de controlekwaliteit is het door de accountantsorganisaties beschikbaar maken van een transparantieverslag. Op deze manier wordt het ook voor de auditcommissie inzichtelijk wat de accountantsorganisatie doet aan het verder verbeteren van de controlekwaliteit. Het beoordelen van controlekwaliteit kan een uitdaging zijn voor auditcommissies. Een onderzoek van de AFM (2015) laat zien dat auditcommissies in Nederland met name hun eigen ervaring en informatie, aangereikt door de raad van bestuur, gebruiken voor dit doel. Uit voorgaande blijkt dat auditkwaliteit een nadrukkelijk aanwezig en belangrijk onderwerp is met een duidelijke link naar de auditcommissie. Zowel de toezichthouders maar ook aandeelhouders hebben een (toenemend) belang in het begrijpen van de rol en het functioneren van de accountant. Hierbij kunnen AQI's een rol spelen.

Het is een uitdaging voor auditcommissies om controlekwaliteit te meten en te evalueren. Waar de accountant zijn tijd en focus besteedt en in welke mate dit is afgestemd met het bestuur en andere betrokkenen is vaak lastig in te schatten voor de auditcommissie. AQI's dra-

Kader 1. Vijf vragen die de auditcommissie zich kan stellen rondom (de start van) het gebruik van AQI's.

1. Wat is het doel van inzetten van AQI's? (verbeteren inzicht in huidige accountant, selecteren nieuwe accountant, etc.)

2. Ten aanzien van welke verantwoordelijkheid/welk onderwerp bestaat de meeste behoefte aan AQI's - met andere woorden waar is de huidige informatievoorziening ontoereikend?

3. Zijn er aspecten met betrekking tot de huidige of inkomende accountant die extra aandacht verdienen?

4. Is de inzet van AQI's gericht op de 'harde' kant (informatievoorziening) of de 'zachte' kant (communicatie, interactie)?

5. Op welke manier kunnen AQI's worden gebruikt om de keten van bestuur, accountant, raad van commissarissen te versterken? 
gen bij aan het oplossen van dit probleem aangezien zij bepaalde aspecten van de controle door de accountant kwantitatief meetbaar maken. AQI's zijn een hulpmiddel dat inzicht creëert en samenwerking kan stimuleren tussen accountants, het bestuur en de auditcommissie door meer verdieping aan te brengen over de controlekwaliteit. Ten aanzien van de AQI's als hulpmiddel is het belangrijk om deze te voorzien van toelichting. De interpretatie van het getal of de trend maakt het verschil, het gaat juist om de beoordeling van de 'getallen' die gepresenteerd worden. AQI's bieden daarmee mogelijkheden om bij te dragen aan het meten en evalueren van de kwaliteit van de accountantscontrole.

Om de gedachtegang van auditcommissies te ondersteunen zijn vijf vragen gedefinieerd die men kan stellen rondom (de start van) het gebruik van AQI's; deze zijn opgenomen in kader 1.

Daarnaast zijn de volgende voordelen van het gebruik van AQI's geformuleerd²:

- verbetert interactie tussen bestuur, raad van commissarissen, auditcommissie en accountant;

- verduidelijkt de verwachtingen en verantwoordelijkheden ten aanzien van controlekwaliteit;

- verbetert de kennis en betrokkenheid bij het proces van de accountantscontrole voor alle leden van de auditcommissies;

- verbetert coördinatie en samenwerkingen in de uitvoering van de controle door de accountant; en

- voorziet de auditcommissie van kwalitatieve en kwantitatieve informatie ter beoordeling van het functioneren van de accountant.

Er is in de praktijk geen lijst met de 'beste' of 'standaard' AQI's. Het is belangrijk dat auditcommissies de AQI's selecteren die voldoen aan hun behoeften en de ondernemingsspecifieke situatie. Zoals eerder beschreven zijn er meerdere internationale bronnen die kunnen worden geraadpleegd en worden gebruikt voor het invullen van de behoeften van de auditcommissies. Een onderzoek van het Center for Audit Quality (2016) en Accountantweek (2016) concludeert dat leden van auditcommissies in meerderheid pleiten voor de mogelijkheid om een eigen op maat gemaakte set indicatoren te gebruiken bij het zoeken naar en beoordelen van de accountant.

De afgelopen jaren is veel gesproken en geschreven over nut en noodzaak van 'objectieve' kwaliteitsmaatstaven. Het CAQ-rapport vat de reacties samen op die voorgestelde set kwaliteitsmaatstaven. Een eerste bevinding is dat een flexibele benadering geprefereerd wordt voor de relatie met de externe accountant: men wil graag het portfolio aan indicatoren kunnen aanpassen aan de specifieke omstandigheden. Bijvoorbeeld bij een initiële controle door een nieuwe accountant is de focus op de externe accountant als leider van het team en de gekozen controleaanpak veel groter dan in het vijfde jaar. Er is ook veel behoefte aan informatie die de auditcommissie moet helpen bij het beoordelen van de meer kwalita- tieve aspecten van de audit(or) - daarvoor is wellicht de dialoog beter geschikt als instrument dan een harde set kwantitatieve indicatoren. Er is consensus dat indicatoren op zich zonder context weinig zeggen over de (uitvoering van) een controleopdracht. Wel is men het erover eens dat het bepalen van de juiste set indicatoren in een iteratief proces gebeuren moet, door de auditcommissie zelf, met voortdurende evaluatie en aanpassing om te voldoen aan de veranderende informatiebehoeften. Daarnaast kan de accountant ook proactief initiatiefnemer zijn van een overzicht met relevante AQI's. Deze kunnen naar behoefte aangevuld worden door de auditcommissie.

\subsection{Canadees model voor AQI's voor auditcommissies}

In Canada is in 2018 door drie instituten (Chartered Professional Accountants of Canada (CPA Canada), the Canadian Public Accountability Board (CPAB) and the Institute of Corporate Directors (ICD)) guidance (CPAB 2018) opgesteld specifiek ten behoeve van auditcommissies over het gebruik van AQI's zoals opgenomen in figuur 3. Deze publicatie bevat een overzicht met door auditcommissies veel gebruikte AQI's en is onverkort relevant en van toegevoegde waarde voor de Nederlandse situatie. Omdat het Canadese model specifiek is opgesteld voor auditcommissies, en dit de invalshoek is van dit artikel is gekozen om dit model als kapstok te gebruiken. De AQI's zijn opgesteld ter ondersteuning aan het creeren van maatwerk bij de verantwoordelijkheden van de auditcommissie.

De auditcommissie-AQI's zijn, op basis van het Canadese model, onderverdeeld in vijf typen:

1. engagement team indicators;

2. audit executive indicatros;

3. management indicators;

4. firm level indicators;

5. client service indicators.

Per type zijn meerdere indicatoren geïdentificeerd die auditcommissies kunnen ondersteunen bij het vervullen van hun verantwoordelijkheden ten aanzien van de accountant. Per indicator is een voorbeelddefinitie van een AQI opgenomen. In dit artikel worden de 'Canadese' indeling en voorbeelden gehanteerd als basis om te identificeren welke AQI's auditcommissies kunnen ondersteunen bij het uitvoeren van hun verantwoordelijkheden op basis van de Nederlandse wet- en regelgeving (zoals opgenomen in bijlage 1).

De 'engagement team indicators' zeggen iets over de kwaliteit en samenstelling van het controleteam. Dit kan worden gezien als een randvoorwaarde voor een goede controle. Hiervoor zijn een vijftal indicatoren gedefinieerd. Wat de waarde van een bepaalde grootheid dient te zijn wordt niet verder aangegeven.

De 'audit execution indicators' zeggen iets over de wijze van uitvoering van de controle. Bijvoorbeeld: hoeveel tijd is aan welke risico's besteed, hoe is de 


\begin{tabular}{|c|c|c|}
\hline Type & Indicator & Example Definitions \\
\hline \multirow[t]{6}{*}{$\begin{array}{l}\text { Engagement } \\
\text { Team Indicators }\end{array}$} & \multirow[t]{2}{*}{$\begin{array}{l}\text { experience of } \\
\text { engagement team }\end{array}$} & $\begin{array}{l}\text { delivery of agreed upon team skills } \\
\text { (industry/specialty/client knowledge) }\end{array}$ \\
\hline & & $\begin{array}{l}\text { years of audit experience of key members } \\
\text { of the engagement team }\end{array}$ \\
\hline & $\begin{array}{l}\text { training and professional } \\
\text { development }\end{array}$ & $\begin{array}{l}\text { number of hours and type of profes- } \\
\text { sional development and technical training } \\
\text { attended by key engagement team } \\
\text { members }\end{array}$ \\
\hline & $\begin{array}{l}\text { turnover of } \\
\text { engagement team }\end{array}$ & $\begin{array}{l}\text { turnover rates of key engagement team } \\
\text { members and/or level }\end{array}$ \\
\hline & $\begin{array}{l}\text { partner/manager } \\
\text { involvement }\end{array}$ & $\begin{array}{l}\text { percentage of audit hours carried out by } \\
\text { senior engagement team members com- } \\
\text { pared to the entire engagement team }\end{array}$ \\
\hline & partner workload & $\begin{array}{l}\text { information about the level of work for } \\
\text { which key engagement partners are } \\
\text { responsible and the number of claims } \\
\text { (including clients and internal responsibili- } \\
\text { ties) receiving their attention }\end{array}$ \\
\hline Type & Indicator & Example Definitions \\
\hline \multirow[t]{6}{*}{$\begin{array}{l}\text { Audit Execution } \\
\text { Indicators }\end{array}$} & audit hours by risk & $\begin{array}{l}\text { time spent by the engagement team } \\
\text { on significant risk areas }\end{array}$ \\
\hline & timing of audit execution & $\begin{array}{l}\text { audit hours by phase (e.g., planning, } \\
\text { interim, year end) }\end{array}$ \\
\hline & $\begin{array}{l}\text { audit progress } \\
\text { milestones }\end{array}$ & $\begin{array}{l}\text { timeline for the completion of the audit } \\
\text { as mapped to key milestones within the } \\
\text { process. }\end{array}$ \\
\hline & technology in the audit & $\begin{array}{l}\text { use of technology initiatives in the audit, } \\
\text { including information about areas of use, } \\
\text { types of tool, number of hours, etc. }\end{array}$ \\
\hline & specialist engagement & $\begin{array}{l}\text { where and how many (measured in hours) } \\
\text { persons with "specialized skill and knowl- } \\
\text { edge" are used in the audit }\end{array}$ \\
\hline & service delivery centres & $\begin{array}{l}\text { amount of audit work centralized at } \\
\text { service centres }\end{array}$ \\
\hline \multirow[t]{3}{*}{$\begin{array}{l}\text { Management } \\
\text { Indicators }\end{array}$} & $\begin{array}{l}\text { management } \\
\text { deliverables }\end{array}$ & $\begin{array}{l}\text { achievement of timing of agreed-upon } \\
\text { deliverables from management to the } \\
\text { auditor }\end{array}$ \\
\hline & $\begin{array}{l}\text { remediation of control } \\
\text { deficiencies }\end{array}$ & $\begin{array}{l}\text { efficiency of remediation of control } \\
\text { deficiencies }\end{array}$ \\
\hline & reliance on controls & $\begin{array}{l}\text { planned/unplanned reliance on internal } \\
\text { controls }\end{array}$ \\
\hline \multirow[t]{4}{*}{$\begin{array}{l}\text { Firm Level } \\
\text { Indicators }\end{array}$} & results of inspections & $\begin{array}{l}\text { results of internal and/or external inspec- } \\
\text { tions specific to the engagement and/or } \\
\text { to the audit firm generally }\end{array}$ \\
\hline & independence & $\begin{array}{l}\text { results of independence findings specific } \\
\text { to the engagement and/or to the audit } \\
\text { firm generally }\end{array}$ \\
\hline & reputation & reputation based on news reports \\
\hline & tone at the top & $\begin{array}{l}\text { tone at the top determined by audit firm } \\
\text { survey results }\end{array}$ \\
\hline \multirow[t]{2}{*}{$\begin{array}{l}\text { Client Service } \\
\text { Indicators }\end{array}$} & $\begin{array}{l}\text { communication with } \\
\text { audit committee }\end{array}$ & $\begin{array}{l}\text { effective and timely communications } \\
\text { between the auditor and the audit } \\
\text { committee and/or management related } \\
\text { specifically to the audit and/or wider } \\
\text { issues of importance (e.g., regulatory } \\
\text { and accounting changes) }\end{array}$ \\
\hline & sharing of Insights & $\begin{array}{l}\text { number and quality of insights gained } \\
\text { and shared with management and the } \\
\text { audit committee }\end{array}$ \\
\hline
\end{tabular}

Figuur 3. Guidance (CPAB 2018) ten behoeve van het gebruik van AQI's door auditcommissies.

voortgang van de controle, worden deadlines gehaald en is er bijvoorbeeld gebruik gemaakt van specialisten. Via deze indicatoren kan de auditcommissie een beter beeld krijgen van de belangrijke issues.

De 'management indicators' zeggen iets over de kwaliteit van de interne beheersing van de organisatie die wordt gecontroleerd. In hoeverre is het bestuur van de organisatie 'in control' en worden bevindingen opgevolgd. Deze indicators hebben niet direct betrekking op de accountant, maar zijn wel van invloed op de contro- lekwaliteit. Het benadrukt nog eens de ketenverantwoordelijkheid. Als de interne beheersing niet op orde is, dan heeft dat direct impact op de aard en diepgang van de werkzaamheden van de accountant en mogelijk op de kwaliteit van de uitkomst.

De 'firm level indicators' zeggen iets over de kwaliteit van de accountantsorganisatie. Bijvoorbeeld: wat zijn de uitkomsten van de inspecties en de opvolging ervan van de toezichthouders zoals AFM en PCAOB, maar ook bijvoorbeeld de NBA, Auditdienst Rijk, onderwijsinspectie, inspectie van de Nederlandse Zorgautoriteit en het Commissariaat van de Media en hoe wordt er met de uitkomsten omgegaan, wordt er van geleerd? Maar ook hoe is er geborgd dat de accountantsorganisatie onafhankelijk is en hoe de toon aan de top is? Indien er bevindingen zijn worden deze geanalyseerd en geremedieerd (afhankelijk van de ernst). Daarnaast worden bevindingen en root cause analysis meegenomen in de trainingen van de accountants. De combinatie van 'engagement team indicators' en 'firm level indicators' geven, naast elkaar, inzicht in de kwaliteit van de accountantsorganisatie en het controleteam, zeker als deze over meerdere jaren worden getoond en waar mogelijk sectorspecifiek kunnen worden vergeleken.

De 'client service indicators' zeggen iets over de kwaliteit van de communicatie en de toegevoegde waarde van de accountant zoals deze wordt waargenomen door, onder meer, het bestuur en de commissarissen. Het gaat hierbij niet alleen om het delen van (tussentijdse) uitkomsten van de controle, maar ook om het tijdig informeren over belangrijke ontwikkelingen.

Ten slotte beschrijft het Canadese model een drietal praktische aandachtspunten voor het eerste gebruik van AQI's, deze zijn opgenomen in kader 2.

Kader 2. Praktische aandachtspunten voor het eerste gebruik van AQI's.

- Houdt het proces begrijpelijk en beheersbaar voor alle be-
trokkenen. Een pragmatisch instelling is belangrijker dan in
het eerste jaar te ambitieus te willen zijn;
- Begin klein, selecteer vijf tot tien AQI's om mee te starten;
en
- Gebruik informatie die beschikbaar is op basis van eerdere
processen, evaluaties en initiatieven of welke makkelijke
beschikbaar kan worden gemaakt door de onderneming en/
of de accountant.

De set van 'Canadese' indicatoren zullen wij toepassen op de verantwoordelijkheden van Nederlandse auditcommissies en bezien in hoeverre zij een bijdrage leveren aan hun rol.

\subsection{Invulling van AQI's voor auditcommissies op basis van Nederlandse verantwoordelijkheden}

Om de relevante AQI's te kunnen 'mappen' aan de werkzaamheden van de accountant en de verantwoordelijkhe- 
den van de auditcommissie daarbij, zijn de werkzaamheden van de accountant op basis van de wettelijke controle in onderstaande figuur weergegeven in de binnenste cirkel. Vervolgens zijn op basis van de analyse van de weten regelgeving de verantwoordelijkheden van de auditcommissie ten aanzien van de accountant samengevat en opgenomen in de buitenste cirkel$^{3}$. In bijlage 1 is de analyse opgenomen op basis waarvan de volgende vijf verantwoordelijkheden van de auditcommissie zijn gedefinieerd.

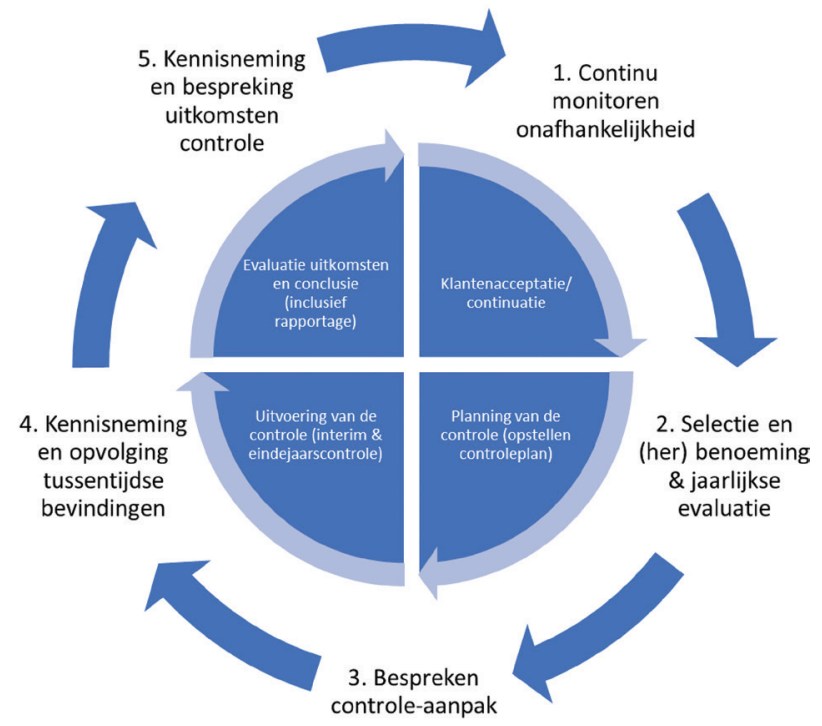

Figuur 4. Fasen van de wettelijke controle door de accountant en de verantwoordelijkheden van de auditcommissie ten aanzien van de accountant.

1. Continue monitoren onafhankelijkheid van de accountant

We beginnen met onafhankelijkheid aangezien dit het fundamenteel beginsel is voor het überhaupt kunnen controleren van een onderneming of organisatie. In de praktijk wordt de onafhankelijkheid beoordeeld als onderdeel van de selectie, maar gezien het belang hebben wij hier een afzonderlijke stap van gemaakt. Het beoordelen en monitoren van de onafhankelijkheid van de accountant is belangrijk in het kader van good governance en is de eerste stap in de cirkel. Zowel de accountant zelf als de auditcommissie heeft hier een verantwoordelijkheid. In Nederland hebben we ten aanzien van onafhankelijkheid vergaande vereisten. Voor OOB's geldt een verbod op adviesdiensten en er gelden strikte rotatievereisten van individuele accountants per klant en van accountantsorganisaties. Enerzijds is de accountant transparant over wat hij/zij in haar rol wel mag/kan doen. Anderzijds is het de verantwoordelijkheid van de auditcommissie om, mede op basis van AQI's, de onafhankelijkheid van de accountant te monitoren en vast te stellen.

In het Canadese model is deze AQI terug te vinden onder 'firm level indicators'. Deze heeft betrekking op zowel de accountant zelf als de accountantsorganisatie als geheel en ziet op mogelijke overtredingen van de onafhankelijkheidsregels. Belangrijker in dit kader is nog dat de accountant en accountantsorganisatie ervoor zorgen dat het risico op onafhankelijkheidsovertredingen wordt geminimaliseerd. Over het proces en de wijze van beheersing is meer informatie te vinden in het transparantieverslag van de accountantsorganisaties.

Ook ligt er een verantwoordelijk voor de auditcommissie om ervoor te zorgen dat er waarborgen zijn om onafhankelijkheidsrisico's te minimaliseren. Het is belangrijk dat er door de auditcommissie en de accountant transparant wordt gecommuniceerd over onafhankelijkheidsvereisten, processen en eventuele schendingen daarvan. In de Nederlandse setting zal een onafhankelijkheidsovertreding van de externe accountant expliciet worden vastgelegd en gecommuniceerd aan de auditcommissie.

\section{Selectie en (her) benoeming en jaarlijkse evaluatie}

De auditcommissie speelt een cruciale rol in de selectie en benoeming van de accountantsorganisatie/externe accountant, zo is het de auditcommissie die $^{4}$ :

- de selectie van de externe accountant voorbereidt;

- advies geeft aan de raad van commissarissen over de voordracht van benoeming of herbenoeming dan wel ontslag van de externe accountant;

- een voorstel doet aan de raad van commissarissen voor de opdracht voor controle van de jaarrekening aan de externe accountant;

- de procedure vaststelt voor de selectie van de externe accountant en de voordracht tot verlening van de opdracht tot het verrichten van de wettelijke controle; en

- beoordeelt of, en zo ja op welke wijze de externe accountant wordt betrokken bij de inhoud en publicatie van financiële berichten anders dan de jaarrekening.

Zoals opgenomen in tabel 1 hieronder zijn voor de selectie en benoeming van de accountant meerdere AQI's relevant, bijvoorbeeld de partner (verantwoordelijk externe accountant) betrokkenheid, de digitalisering van de controle en de betrokkenheid van specialisten, maar ook de reputatie van de accountantsorganisatie. In het Canadese model zijn de AQI's voor selectie van de accountant vooral te vinden onder de 'engagement team indicators' en daarnaast onder de 'firm level indicators'. Voor de andere AQI's geldt dat zij veel meer een resultante zijn van de controle en optreden van de accountant. Auditcommissies zouden zich, met name bij een evaluatie en (her)benoeming ook moeten verdiepen in de 'management indicators' aangezien de kwaliteit van de interne beheersing mogelijk impact heeft op de eisen die aan de accountant(scontrole) worden gesteld. Zo zal de accountant in een organisatie die sterk geautomatiseerd is en waar de beheersing op orde is, veel beter data-analyse kunnen toepassen dan bij organisaties die minder zijn ontwikkeld op dit gebied.

De AQI's kunnen worden gebruikt voor het eerste assessment van de accountant en kunnen ondersteunend zijn aan het selectieproces. Echter in de praktijk blijkt dat 
de 'zachtere' kant minstens zo belangrijk of zelfs belangrijker is. De 'board room presence' van een accountant en zijn/haar authenticiteit, inclusief de kwaliteit van mondelinge communicatie zijn belangrijk in de keuze van een accountant. Private sessies hebben in deze belangrijke toegevoegde waarde voor de auditcommissie en zijn niet in AQI's opgenomen. Daarnaast zijn factoren, die niet in (harde) AQI's te verwerken zijn, als deskundigheid en ervaring van het team van groot belang voor de keuze van een accountant. AQI's zijn daarom van waarde voor de auditcommissie maar niet de doorslaggevende factor bij de selectie en (her)benoeming.

De auditcommissie rapporteert jaarlijks aan de raad van commissarissen over het functioneren van en de ontwikkelingen in de relatie met de externe accountant. Deze rapportages dienen ook als basis voor het herbenoemen van de accountant. In deze fase gaat het om de totaalbeoordeling van het functioneren van de accountant, deze beoordeling is veel 'rijker' dan bij de selectie aangezien dan ook AQI's met betrekking tot de 'audit executie' en de 'client service' meegenomen kunnen worden. De Canadese indicatoren bieden hier een goede basis voor. Ook hier geldt dat het verhaal achter de AQI's misschien nog wel belangrijker is. Bijvoorbeeld indien de accountant niet tijdig rapporteert moet op zoek gegaan worden naar de oorzaak. Komt het doordat de accountant zijn afspraken niet nakomt of heeft de gecontroleerde organisatie tijdig of onvoldoende de gevraagde controle-informatie opgeleverd? Deze analyse kan ook ondersteunend zijn bij de besprekingen van de fee en eventuele overruns.

Naast de evaluatie van de externe accountant gaat het ook om hoe de organisatie omgaat met de externe accountant, vragen ('management indicators') die daartoe van belang zijn betreffen:

- worden de door de accountant gestelde vragen snel beantwoord?

- mag een ondergeschikte de vragen van de externe accountant beantwoorden of alleen de $\mathrm{CFO} / \mathrm{CEO}$ ?

- wordt de door de accountant gevraagde informatie snel verstrekt?

- is er een goede discussie mogelijk tussen accountant en de verantwoordelijken bij de onderneming en heeft dit invloed op de mening van de accountant?

De informatie op basis van deze AQI's vormt de basis voor een kwalitatieve beoordeling door de auditcommissie en uiteindelijk de gehele raad van commissarissen.

\section{Bespreken controleaanpak}

Ook ten aanzien van de planning en uitvoering van de controle heeft de auditcommissie een rol. In dat kader bespreekt de auditcommissie jaarlijks met de externe accountant:
- de reikwijdte en materialiteit van het auditplan;

- de belangrijkste risico's van de jaarverslaggeving die de externe accountant heeft benoemd in het auditplan.

Vergelijkbaar met de selectie en benoeming zijn er meerdere AQI's van toegevoegde waarde bij deze taak van de auditcommissie. Met name ten aanzien van de planning en inrichting van de controle zijn de hardere indicatoren als controle-uren per risico en tijdsbesteding per fase van de controle van belang. Het betreffen vooral de indicatoren opgenomen onder de 'audit executie'.

Aan de Canadese AQI's kunnen ons inziens nog worden toegevoegd: de gehanteerde materialiteit, de reikwijdte van de controle (welk deel van de cijfers wordt volledig gecontroleerd, welk deel wordt gereviewed en welk deel valt buiten de scope van de accountant), inzet van buitenlandse accountants, locatiebezoek door de accountant en de risicoanalyse van de accountant. Zoals eerder beschreven geven de combinatie van 'engagement team indicators' en 'firm level indicators', naast elkaar en in verhouding tot elkaar, inzicht in de kwaliteit van de accountantsorganisatie en het controleteam, zeker als deze over meerdere jaren worden getoond en waar mogelijk sectorspecifiek kunnen worden vergeleken.

\section{Kennisneming en opvolging tussentijdse bevindingen}

Gedurende het controleproces is het belangrijk dat de auditcommissie vinger aan de pols houdt. Tot de verantwoordelijkheid behoort immers het monitoren van de doeltreffendheid van het interne beheersingssysteem, het eventuele interne auditsysteem en het risicomanagementsysteem met betrekking tot de financiële verslaggeving van de rechtspersoon. Met name de uitkomsten van de interimcontrole geven de auditcommissie hier goede inzichten over. In het Canadese model is de AQI die hier relevant voor is onderdeel van de 'client service indicators'. De relevante indicator heeft betrekking op de effectiviteit en tijdigheid van de communicatie tussen de accountant en de auditcommissie. Wel zeggen de uitkomsten van de interimcontrole en de opvolging ervan iets over de AQI's die betrekking hebben op de 'management indicators'. Wat is de kwaliteit van de interne beheersing?

In het kader van de 'client service indicators' is het belangrijk dat de accountant rapporteert over belangrijke ontwikkelingen op het gebied van verslaggevingsstandaarden, niet alleen aan het bestuur maar ook aan de auditcommissie. Ook is het belangrijk dat accountants tijdig aan de bel trekken bij de auditcommissie als zij tegen non-compliance en/of fraudecases aanlopen. In de Nederlandse setting heeft een controlerend accountant en de auditcommissie een toezichthoudende rol ten aanzien van de integriteit van de financiële verslaggeving. Ook is de voorzitter van de auditcommissie het aanspreekpunt 
voor de externe accountant wanneer hij bij de uitvoering van zijn opdracht een misstand of onregelmatigheid constateert of vermoedt. Ten aanzien van het thema kennisneming en opvolging tussentijdse bevindingen bieden de AQI's een beperkte steun.

\section{Kennisnemen en bespreking uitkomsten controle}

De laatste fase van de controle is de evaluatie van de uitkomsten en het trekken van conclusies. De accountant zal de uitkomst van de controle rapporteren via het accountantsverslag en de controleverklaring. Met name het accountantsverslag geeft de auditcommissie een goed beeld van de uitvoering van de controle, de issues waar de accountant tegenaan is gelopen en hoe hij tot zijn conclusies en eindoordeel is gekomen. Ook is in het accountantsverslag terug te lezen: de reikwijdte van de controle, de gehanteerde materialiteit, de kernpunten van de controle en of de accountant onafhankelijk is geweest gedurende de controle. In Nederland is deze informatie ook terug te vinden in de controleverklaring. Deze verklaring zelf geeft aan of de jaarrekening een getrouw beeld geeft en of het bestuursverslag voldoet aan de wettelijke vereisten; ook worden hierin de kernpunten van de controle opgenomen (de zogenaamde key audit matters). De AQI's die hier betrekking op hebben betreffen de 'client service indicators'. Naast de schriftelijke communicatie is de mondelinge communicatie van belang. In de eerdere publicatie (De Bos et al. 2020) gingen wij in op het belang van de mondelinge toelichting van de accountant. Ook de 'private sessies' voegen met name waarde toe. Hierover zijn in het Canadese model geen AQI's opgenomen.

Samenvattend zijn wij van mening dat met name transparantie en tijdige communicatie door de accountant naar zowel bestuur als auditcommissie/raad van commissarissen een belangrijke kwalitatieve AQI is. De accountant kan immers gezien worden als de 'ogen en oren' van de auditcommissie. Het meten van de kwaliteit van de communicatie is een uitdaging door de harde en tegelijkertijd zachte aard van communicatie en hoe deze verzonden en ontvangen wordt. Metacommunicatie is daardoor van groot belang en het geven en ontvangen van constructieve feedback speelt daarbij een grote rol.

Ter afsluiting kan worden opgemerkt dat AQI's van waarde zijn voor auditcommissies. De AQI's geven de auditcommissie informatie die mogelijk van invloed is op kwaliteit van de controle. Hierbij is het wel van belang om op te merken om deze indicatoren in perspectief te plaatsen door naar de ontwikkeling van de indicator in de tijd te kijken.

Bijvoorbeeld een partnerbetrokkenheid van 5\% zegt mogelijk niet zoveel, maar als dit percentage in de tijd gaat stijgen of dalen wordt het interessant of als dit percentage afwijkt van hetgeen gebruikelijk is (de benchmark),
Kader 3. Praktische aandachtspunten en aspecten die van belang zijn bij de selectie van de juiste AQI's.

- De unieke aard van de onderneming;

- De specifieke onderdelen van de onderneming met significant 'audit risk';

- Specifieke onderdelen van de accountantscontrole waarover meer informatie/transparantie gewenst is;

- Onderwerpen die belangrijk zijn voor de auditcommissie ten aanzien van het beoordelingen van het functioneren van de accountant;

- Thema's die terugkomen in rapporten/onderzoek van externe toezichthouders zoals de AFM;

- Actuele thema's die invloed hebben op de accountantscontrole, zoals COVID-19 en Brexit;

- AQI's die de accountant en/of het bestuur (onderling) gebruiken;

- Mate waarin de accountant reeds in staat is informatie te delen op basis waarvan goede gesprekken gevoerd kunnen worden;

- Informatie die reeds is opgenomen in de transparantieverslagen van accountantsorganisaties; en

- De uitkomsten van de jaarlijkse evaluatie van het functioneren van de accountant.

maar bijvoorbeeld ook ten opzichte van het gemiddelde van de accountantsorganisaties en indien mogelijk naar het gemiddelde van de (klant)sector. Bij dit alles moeten we ons wel realiseren dat om echt een goed beeld te krijgen van de kwaliteit naar het verhaal achter de AQI's gekeken dient te worden. Voor de selectie van de juiste AQI's heeft het Canadese model 10 aandachtspunten en aspecten die van belang zijn geformuleerd. Deze zijn opgenomen in kader 3 .

Ten slotte hebben wij de verantwoordelijkheden van de auditcommissie ten aanzien van de accountant afgezet tegen enerzijds de relevante AQI's en anderzijds de fasen van de werkzaamheden van de accountant (zie tabel 1). Het (interne) proces van klantacceptatie en continuatie is hierbij buiten beschouwing gelaten. Hierdoor is inzichtelijk welke AQI's de auditcommissie kunnen ondersteunen bij haar verantwoordelijkheden. De in de tabel gebruikte AQI's zijn mede gebaseerd op het in Canada gepubliceerde overzicht (CAPB 2018) met door auditcommissies veel gebruikte AQI's en waar relevant uitgebreid en aangepast. Per AQI is opgenomen of deze 'hard' (kwantitatief) of 'zacht' (kwalitatief) is.

Deze AQI's zijn opgesteld ter ondersteuning aan het creëren van maatwerk bij de verantwoordelijkheden van de auditcommissie. 
Tabel 1. Verantwoordelijkheden van de auditcommissie ten aanzien van de accountant afgezet tegen enerzijds de relevante AQI's en anderzijds de fasen van de werkzaamheden van de accountant.

\begin{tabular}{|c|c|c|c|c|c|c|c|c|}
\hline \multirow{2}{*}{\multicolumn{2}{|c|}{ Thema }} & \multirow[t]{2}{*}{ AQI's*) } & \multirow{2}{*}{$\begin{array}{c}\text { Type } \\
\text { AQI } \\
\text { Hard/ } \\
\text { Zacht }\end{array}$} & \multirow{2}{*}{$\begin{array}{c}\text { Type AQI } \\
\text { Betrekking op: }\end{array}$} & \multirow{2}{*}{$\begin{array}{c}\text { Initiële } \\
\text { selectie } \\
\text { accountant }\end{array}$} & \multicolumn{3}{|c|}{ Accountantscontrole } \\
\hline & & & & & & Planning & Uitvoering & $\begin{array}{l}\text { Evaluatie } \\
\text { uitkomsten } \\
\text { en conclusie }\end{array}$ \\
\hline 1. & $\begin{array}{l}\text { Continu } \\
\text { monitoren } \\
\text { onafhankelijkheid }\end{array}$ & $\begin{array}{l}\text { Bevindingen ten aanzien van de onafhankelijkheid specifiek ten } \\
\text { aanzien van de opdracht en/of de accountantsorganisatie als geheel }\end{array}$ & $\mathrm{H}$ & $\begin{array}{c}\text { Accountantsorganisatie } \\
\text { (firm level indicators) } \\
\text { / Controle team } \\
\text { (engagement team } \\
\text { indicators) }\end{array}$ & $\sqrt{ }$ & $\sqrt{ }$ & - & - \\
\hline \multirow[t]{20}{*}{2.} & \multirow{20}{*}{$\begin{array}{l}\text { Selectie en (her) } \\
\text { benoeming } \\
\text { en jaarlijkse } \\
\text { evaluatie }\end{array}$} & Aantal jaren controle ervaring van kern controleteam & $\mathrm{H}$ & \multirow[t]{7}{*}{ Controle team } & $\sqrt{ }$ & $\sqrt{ }$ & - & - \\
\hline & & $\begin{array}{c}\text { Aantal uren en type technische training en professionele } \\
\text { ontwikkeling }\end{array}$ & $\mathrm{H}$ & & $\sqrt{ }$ & - & - & - \\
\hline & & Verloop in het controleteam per niveau & $\mathrm{H}$ & & - & $\sqrt{ }$ & - & - \\
\hline & & $\begin{array}{c}\text { Partner/manager betrokkenheid ( } \% \text { of \# uren ten opzichte van } \\
\text { totaal, wie beantwoordt vragen van de auditcommissie en } \\
\text { aansturing van het team door de partner) }\end{array}$ & $\mathrm{H}$ & & $\sqrt{ }$ & $\sqrt{ }$ & $\sqrt{ }$ & $\sqrt{ }$ \\
\hline & & Partner boardroom presence & Z & & $\sqrt{ }$ & $\sqrt{ }$ & & $\sqrt{ }$ \\
\hline & & Communicatie skills (schriftelijk en mondeling) & $\mathrm{Z}$ & & $\sqrt{ }$ & $\sqrt{ }$ & $\sqrt{ }$ & $\sqrt{ }$ \\
\hline & & Partner werkbelasting & $\mathrm{H}$ & & $\sqrt{ }$ & $\sqrt{ }$ & - & - \\
\hline & & Digitalisering van de controle & $\mathrm{H}$ & \multirow{2}{*}{$\begin{array}{l}\text { Aanpak / Uitvoering } \\
\text { van de controle (audit } \\
\text { execution indicators) }\end{array}$} & $\sqrt{ }$ & $\sqrt{ }$ & $\sqrt{ }$ & - \\
\hline & & Betrokkenheid van specialisten & $\mathrm{H}$ & & $\sqrt{ }$ & - & $\sqrt{ }$ & - \\
\hline & & Inspectieresultaten & $\mathrm{H}$ & \multirow[t]{3}{*}{ Accountantsorganisatie } & $\sqrt{ }$ & $\sqrt{ }$ & - & - \\
\hline & & Reputatie & Z & & $\sqrt{ }$ & - & - & - \\
\hline & & Toon aan de top/cultuur & Z & & $\sqrt{ }$ & $\sqrt{ }$ & - & - \\
\hline & & $\begin{array}{l}\text { Effectiviteit en tijdigheid van communicatie tussen accountant en } \\
\text { de auditcommissies en/of bestuur }\end{array}$ & $\mathrm{H} \& \mathrm{Z}$ & \multirow[t]{3}{*}{ Client service indicators } & - & $\sqrt{ }$ & $\sqrt{ }$ & $\sqrt{ }$ \\
\hline & & Beoordelingsgesprek met de accountant/private sessie & $\mathrm{H} \& \mathrm{Z}$ & & - & - & - & - \\
\hline & & Delen van kennis en thought leadership & $\mathrm{H}$ & & - & - & - & - \\
\hline & & Metacommunicatie & $H \& Z$ & Client service indicators & - & - & - & - \\
\hline & & Tijdigheid en kwaliteit van oplevering informatie & $\mathrm{H}$ & \multirow{3}{*}{$\begin{array}{l}\text { Bestuur en management } \\
\text { van de gecontroleerde } \\
\text { (management indicators) }\end{array}$} & - & $\sqrt{ }$ & $\sqrt{ }$ & - \\
\hline & & Opvolging van geïdentificeerde gebreken in beheersmaatregelen & $\mathrm{H} \& \mathrm{Z}$ & & - & $\sqrt{ }$ & - & - \\
\hline & & Mate van steunen op beheersingsmaatregelen & $\mathrm{H}$ & & - & $\sqrt{ }$ & - & - \\
\hline & & $\begin{array}{l}\text { Benchmarken offerte van de accountant tav sector AQI's en } \\
\text { analyse van verschillen }\end{array}$ & $\mathrm{H}$ & Alle categorieën & $\sqrt{ }$ & - & - & - \\
\hline \multirow[t]{13}{*}{3.} & \multirow{13}{*}{$\begin{array}{l}\text { Bespreken } \\
\text { controleaanpak }\end{array}$} & Controle-uren per risico & $\mathrm{H}$ & \multirow{13}{*}{$\begin{array}{c}\text { Aanpak/Uitvoering } \\
\text { van de controle (audit } \\
\text { execution indicators) }\end{array}$} & $\sqrt{ }$ & $\sqrt{ }$ & $\sqrt{ }$ & $\sqrt{ }$ \\
\hline & & Tijdsbesteding van controle per fase & $\mathrm{H}$ & & $\sqrt{ }$ & $\sqrt{ }$ & $\sqrt{ }$ & $\sqrt{ }$ \\
\hline & & Digitalisering van de controle & $\mathrm{H}$ & & $\sqrt{ }$ & $\sqrt{ }$ & $\sqrt{ }$ & $\sqrt{ }$ \\
\hline & & Project management - milestones definiëren/monitoren en follow & $\mathrm{H}$ & & $\sqrt{ }$ & $\sqrt{ }$ & $\sqrt{ }$ & $\sqrt{ }$ \\
\hline & & Beschikbare uren van controleteam & $\mathrm{H}$ & & $\sqrt{ }$ & $\sqrt{ }$ & $\sqrt{ }$ & $\sqrt{ }$ \\
\hline & & Gehanteerde materialiteit & $\mathrm{H}$ & & $\sqrt{ }$ & $\sqrt{ }$ & $\sqrt{ }$ & $\sqrt{ }$ \\
\hline & & Reikwijdte van de controle & $\mathrm{H}$ & & $\sqrt{ }$ & $\sqrt{ }$ & $\sqrt{ }$ & $\sqrt{ }$ \\
\hline & & Inzet buitenlandse accountants & $\mathrm{H}$ & & $\sqrt{ }$ & $\sqrt{ }$ & $\sqrt{ }$ & $\sqrt{ }$ \\
\hline & & $\begin{array}{l}\text { Locatiebezoek door de accountant - bespreken (voorlopige) } \\
\text { bevindingen en beoordelen zachte kant (cultuur, toon aan de top } \\
\text { etc) }\end{array}$ & $\mathrm{H} / \mathrm{Z}$ & & $\sqrt{ }$ & $\sqrt{ }$ & $\sqrt{ }$ & $\sqrt{ }$ \\
\hline & & Teaming (samenwerking, diversiteit) & Z & & $\sqrt{ }$ & $\sqrt{ }$ & $\sqrt{ }$ & $\sqrt{ }$ \\
\hline & & Mate van omgang met tijds- en capaciteitsdruk & Z & & $\sqrt{ }$ & $\sqrt{ }$ & $\sqrt{ }$ & $\sqrt{ }$ \\
\hline & & Betrokkenheid van specialisten & $\mathrm{H}$ & & $\sqrt{ }$ & - & $\sqrt{ }$ & $\sqrt{ }$ \\
\hline & & Gebruik van service centers & $\mathrm{H}$ & & $\sqrt{ }$ & $\sqrt{ }$ & $\sqrt{ }$ & $\sqrt{ }$ \\
\hline \multirow[t]{5}{*}{4.} & \multirow{5}{*}{$\begin{array}{l}\text { Kennisneming } \\
\text { en opvolging } \\
\text { tussentijdse } \\
\text { bevindingen }\end{array}$} & $\begin{array}{l}\text { Effectiviteit en tijdigheid van communicatie tussen accountant } \\
\text { en de auditcommissies en/of bestuur (o.a. bij niet verwachte } \\
\text { bevindingen) }\end{array}$ & $H \& Z$ & Client service indicators & - & $\sqrt{ }$ & $\sqrt{ }$ & $\sqrt{ }$ \\
\hline & & $\begin{array}{l}\text { Project management - milestones definiëren/monitoren en follow } \\
\text { up, tijdige bespreking van urenoverschrijdingen) }\end{array}$ & $\mathrm{H}$ & $\begin{array}{l}\text { Aanpak/Uitvoering van } \\
\text { de controle }\end{array}$ & $\sqrt{ }$ & $\sqrt{ }$ & $\sqrt{ }$ & $\sqrt{ }$ \\
\hline & & Tijdigheid en kwaliteit van oplevering informatie & $\mathrm{H}$ & \multirow{3}{*}{$\begin{array}{l}\text { Bestuur en management } \\
\text { van de gecontroleerde }\end{array}$} & - & $\sqrt{ }$ & $\sqrt{ }$ & $\sqrt{ }$ \\
\hline & & Opvolging van geïdentificeerde gebreken in beheersmaatregelen & $\mathrm{H} \& \mathrm{Z}$ & & - & $\sqrt{ }$ & - & $\sqrt{ }$ \\
\hline & & Mate van steunen op beheersingsmaatregelen & $\mathrm{H}$ & & - & $\sqrt{ }$ & - & $\sqrt{ }$ \\
\hline \multirow[t]{2}{*}{5.} & \multirow{2}{*}{$\begin{array}{l}\text { Kennisneming } \\
\text { en bespreking } \\
\text { uitkomsten } \\
\text { controle }\end{array}$} & $\begin{array}{l}\text { Effectiviteit en tijdigheid van communicatie tussen accountant en } \\
\text { de auditcommissies en/of bestuur }\end{array}$ & $\mathrm{H} \& \mathrm{Z}$ & Client service indicators & - & $\sqrt{ }$ & $\sqrt{ }$ & $\sqrt{ }$ \\
\hline & & $\begin{array}{l}\text { Project management }- \text { milestones definiëren/monitoren en follow } \\
\text { up }\end{array}$ & $\mathrm{H}$ & $\begin{array}{l}\text { Aanpak/Uitvoering van } \\
\text { de controle }\end{array}$ & $\sqrt{ }$ & $\sqrt{ }$ & $\sqrt{ }$ & $\sqrt{ }$ \\
\hline
\end{tabular}

*) Op basis van het Canadese model en toevoegingen van de auteurs van dit artikel.

\section{Conclusie en praktische aandachtspunten voor de auditcommissie bij het gebruik van AQI's}

\subsection{Conclusies}

Op basis van de verantwoordelijkheden van de auditcommissie, de ontwikkeling van en toenemende aandacht voor AQI's bevat dit artikel een overzicht van de verantwoordelijkheden van de auditcommissie ten aanzien van de accountant afgezet tegen enerzijds de relevante AQI's en anderzijds de verschillende fasen van de werkzaamheden van de accountant. Hierdoor is inzichtelijk welke AQI's de auditcommissie kunnen ondersteunen bij hun verantwoordelijkheden.

Een kenmerk van AQI's is dat zij meestal 'hard', ofwel kwantitatief, zijn. Zoals bij alle indicatoren is een kwalitatieve beoordeling van deze indicatoren van groot belang. Er moet op zoek gegaan worden naar 
relatieve betekenis van én de ontwikkeling van de AQI in de tijd. Daarnaast moet de AQI in perspectief worden gezet worden, wat is het verhaal achter het cijfer? Ook worden AQI's waardevoller als er relaties worden gelegd. Bijvoorbeeld de combinatie van 'engagement team indicators' en 'firm level indicators', de kwaliteit van de accountantsorganisatie en het controleteam, de ontwikkeling over meerdere jaren en waar mogelijk sectorspecifiek wordt gemaakt.Voorlopig kan geconcludeerd worden dat AQI's voor auditcommissies meer ondersteunend zijn dan cruciaal. De AQI's vergroten de informatievoorziening naar de auditcommissie voor het uitvoeren van hun taken en het nemen van beslissingen ten aanzien van de accountant, maar lijken (nog) geen alomvattend wondermiddel.

Het advies is om auditcommissies in het verslag van de raad van commissarissen melding te laten ma- ken van de mate van gebruik van AQI's. Door deze informatie met alle belanghebbenden te delen wordt de kennis en waarde van AQI's breder bekend en gedeeld. Ook rechtstreekse communicatie en een dialoog tussen de auditcommissie en de accountant over de AQI's en de uitkomst daarvan, zal bijdragen aan de verdere stimulering van het gebruik en inbedding van AQI's voor en door auditcommissie om daarmee als basis te dienen voor het periodiek bespreken van de kwaliteit van de controle.

Daarnaast kan de auditcommissie de conclusies op basis van de AQI's samen met de andere elementen die een rol spelen, bespreken met de raad van commissarissen ten behoeve van het evalueren van het functioneren van de accountant en het borgen van de controlekwaliteit.

Ten slotte is duidelijk dat (nog) niet voor iedere taak van de auditcommissie geschikte AQI's beschikbaar zijn.

- Prof. dr. Auke de Bos RA is hoogleraar Bedrijfseconomie aan de Erasmus Universiteit waar hij doceert aan de Master Financieel Recht en de Accountancy Opleiding. Daarnaast is hij bestuurder bij EY Accountants.

- Drs. Martijn de Jong RA is Corporate Governance specialist bij EY. Hij is lid van de werkgroep jaarverslag/Corporate Governance van de Raad voor de Jaarverslaggeving en de NBA-werkgroep Corporate Governance.

\section{Noten}

1. Of de raad van commissarissen als geheel, indien geen auditcommissie aanwezig is.

2. Mede gebaseerd op https://www.cpacanada.ca/en/business-and-accounting-resources/audit-and-assurance/enhancing-audit-quality/publications/guide-to-audit-quality-indicators

3. Voor de verantwoordelijkheid van de auditcommissie ten aanzien van het inhoudelijk interpreteren en beoordelen van de resultaten/uitkomsten van de wettelijke controle, het vaststellen van de procedure voor de selectie van de externe accountant en de voordracht tot verlening van de opdracht tot het verrichten van de wettelijke controle en de verantwoordelijkheid van de auditcommissie bij de werkzaamheden van de externe accountant bij de inhoud en publicatie van financiële berichten anders dan de jaarrekening, zijn geen AQI's relevant en derhalve is deze verantwoordelijkheid in het restant van het artikel buiten beschouwing gelaten.

4. op basis van de wet- en regelgeving zoals uiteengezet in bijlage 1 .

\section{Literatuur}

- Accountantweek 2016 - auditkwaliteit - auditcommissies prefereren indicatoren op maat https://accountantweek.nl/artikel/auditkwaliteit-audit-commissies-prefereren-indicatoren-op-maat

- AFM (Autoriteit Financiële Markten) 2015 Verkenning naar kritisch vermogen auditcommissies bij verslaggeving en accountantscontrole. https://www.afm.nl/ /profmedia/files/rapporten/2015/auditcommissies.pdf?la $=$ nl-NL

- AFM (Autoriteit Financiële Markten) (2020) Auditcommissies kunnen direct invloed hebben op kwaliteit. https://verslaggeving.afm.nl/ agenda-2020/blog-accountancy-linda-hobbelt/

- Center for Audit Quality (CAQ) (2016) AQIs. The journey and path ahead. https://www.thecaq.org/wp-content/uploads/2019/03/auditqualityindicators_journeyandpath2016-2.pdf

- CPAB (Canadian Public Accountability Board (2018) Audit Quality Indicators Final Report. https:/www.cpab-ccrc.ca/docs/ default-source/thought-leadership-publications/2018-aqi-final-report-en.pdf?sfvrsn=5af68dba_12
- CTA (Commissie toekomst accountancysector) (2020) Vertrouwen op controle. https://www.nba.nl/globalassets/documenten/cta-eindrapport-vertrouwen-op-controle-30-01-2020.pdf

- De Bos, De Jong M, Strating H (2020) Percepties door commissarissen van de communicatie door de accountant. Maandblad voor Accountancy en Bedrijfseconomie 94(1-2): 65-76. https://doi. org/10.5117/mab.94.49238

- European Parliament (2014) Regulation 537/2014 of the European Parliament and of the Council of 16 April 2014 on specific requirements regarding statutory audit of public-interest entities and repealing Commission Decision 2005/909/EC - New EU regulatory framework on audit, Article 27(1)(c) and 27(2). EUR-Lex - 32014R0537 - EN - EUR-Lex (europa.eu)

- FEE (Federation of European Accountants) (2015) Overview of Audit Quality Indicators initiatives. http://www.accountancyeurope.eu/wp-content/uploads/1607_Update_of_Overview_of AQIs.pdf 
[ Lückerath-Rovers M, De Bos A (2014) Nationaal Commissarissen onderzoek 2014. TIAS, Erasmus Universiteit Rotterdam. https://www.tias.edu/docs/default-source/Kennisartikelen/ nco2014.pdf

- Majoor GCM (2016) Audit Quality Indicators; het ei van Columbus? Maandblad voor Accountancy en Bedrijfseconomie 90(4): 112-115. https://doi.org/10.5117/mab.90.31281

- NBA (Koninklijke Nederlandse Beroepsorganisatie van Accountants) (2016) NBA-handreiking 1135 Publicatie kwaliteitsfactoren. https://www.nba.nl/globalassets/wet--en-regelgeving/ nba-handreikingen/nba-handreiking_1135_publicatie_kwaliteitsfactoren.pdf

- Pinello AS, Volkan AG, Franklin J, Levatino M, Tiernan K (2019) The PCAOB Audit Quality Indicator Framework Project: Feedback from stakeholders. Journal of Business \& Economics Research 16(1): 1-8. https://doi.org/10.19030/jber.v16i1.10280

- The World Bank, Centre for Financial Reporting Reform (CFRR) (2018), Governance Global Practice - Reporting by Public Oversight Bodies. https://cfrr.worldbank.org/publications/reporting-public-oversight-bodies

\section{Bijlage 1}

Analyse verantwoordelijkheden auditcommissies op basis van Nederlandse wet- en regelgeving.

\begin{tabular}{|c|c|c|}
\hline $\begin{array}{l}\text { Wet- en regelgeving } \\
\text { Verantwoordelijkheden van de } \\
\text { auditcommissie }\end{array}$ & Vereiste & Thema \\
\hline Besluit instelling auditcommissie & $\begin{array}{l}\text { Het beoordelen en monitoren van de onafhankelijkheid van de externe accountant } \\
\text { (zie Wta), waarbij met name wordt gelet op de verlening van nevendiensten aan de } \\
\text { rechtspersoon. }\end{array}$ & $\begin{array}{l}\text { Continu monitoren } \\
\text { onafhankelijkheid }\end{array}$ \\
\hline $\begin{array}{l}\text { Nederlandse Corporate Governance } \\
\text { Code - verantwoordelijkheden van } \\
\text { de auditcommissie met betrekking } \\
\text { tot de selectie, beoordeling en (her) } \\
\text { benoeming) externe accountant }\end{array}$ & De auditcommissie bereidt de selectie van de externe accountant voor. & $\begin{array}{l}\text { - Selectie en (her) benoeming en } \\
\text { jaarlijkse evaluatie }\end{array}$ \\
\hline $\begin{array}{l}\text { Nederlandse Corporate Governance } \\
\text { Code - verantwoordelijkheden van } \\
\text { de auditcommissie met betrekking } \\
\text { tot de selectie, beoordeling en (her) } \\
\text { benoeming) externe accountant }\end{array}$ & $\begin{array}{l}\text { De auditcommissie geeft advies aan de raad van commissarissen over de voordracht } \\
\text { van benoeming of herbenoeming dan wel ontslag van de externe accountant. }\end{array}$ & $\begin{array}{l}\text { - Selectie en (her) benoeming en } \\
\text { jaarlijkse evaluatie }\end{array}$ \\
\hline $\begin{array}{l}\text { Nederlandse Corporate Governance } \\
\text { Code - aansturing van de externe } \\
\text { accountant }\end{array}$ & $\begin{array}{l}\text { De auditcommissie doet een voorstel aan de raad van commissarissen voor de } \\
\text { opdracht voor controle van de jaarrekening aan de externe accountant (best practice } \\
\text { bepaling 1.6.3). }\end{array}$ & $\begin{array}{l}\text { - Selectie en (her) benoeming en } \\
\text { jaarlijkse evaluatie }\end{array}$ \\
\hline Besluit instelling auditcommissie & $\begin{array}{l}\text { Het vaststellen van de procedure voor de selectie van de externe accountant en de } \\
\text { voordracht tot verlening van de opdracht tot het verrichten van de wettelijke controle. }\end{array}$ & $\begin{array}{l}\text { - Selectie en (her) benoeming en } \\
\text { jaarlijkse evaluatie }\end{array}$ \\
\hline $\begin{array}{l}\text { Nederlandse Corporate Governance } \\
\text { Code - aansturing van de externe } \\
\text { accountant }\end{array}$ & $\begin{array}{l}\text { De auditcommissie beoordeelt of, en zo ja op welke wijze de externe accountant } \\
\text { wordt betrokken bij de inhoud en publicatie van financiële berichten anders dan de } \\
\text { jaarrekening (best practice bepaling 1.7.3). }\end{array}$ & $\begin{array}{l}\text { - Selectie en (her) benoeming en } \\
\text { jaarlijkse evaluatie }\end{array}$ \\
\hline $\begin{array}{l}\text { Nederlandse Corporate Governance } \\
\text { Code - verantwoordelijkheden van } \\
\text { de auditcommissie met betrekking } \\
\text { tot de selectie, beoordeling en (her) } \\
\text { benoeming) externe accountant }\end{array}$ & $\begin{array}{l}\text { De auditcommissie rapporteert jaarlijks aan de raad van commissarissen over het } \\
\text { functioneren van en de ontwikkelingen in de relatie met de externe accountant. }\end{array}$ & $\begin{array}{l}\text { - Selectie en (her) benoeming en } \\
\text { jaarlijkse evaluatie }\end{array}$ \\
\hline $\begin{array}{l}\text { Nederlandse Corporate Governance } \\
\text { Code - aansturing van de externe } \\
\text { accountant }\end{array}$ & $\begin{array}{l}\text { De auditcommissie bespreekt jaarlijks met de externe accountant de reikwijdte en } \\
\text { materialiteit van het auditplan en de belangrijkste risico's van de jaarverslaggeving } \\
\text { die de externe accountant heeft benoemd in het auditplan, en de bevindingen en de } \\
\text { uitkomsten van de controlewerkzaamheden bij de jaarrekening en de management } \\
\text { letter (best practice bepaling 1.7.2). }\end{array}$ & - Bespreken controle-aanpak \\
\hline \multirow[t]{2}{*}{ Besluit instelling auditcommissie } & \multirow{2}{*}{$\begin{array}{l}\text { Het monitoren van de wettelijke controle van de jaarrekening en de geconsolideerde } \\
\text { jaarrekening, in het bijzonder de uitvoering van de controle met inachtneming van de } \\
\text { beoordeling van de Autoriteit Financiële Markten. }\end{array}$} & $\begin{array}{l}\text { Kennisneming en opvolging } \\
\text { tussentijdse bevindingen }\end{array}$ \\
\hline & & $\begin{array}{l}\text { - Kennisneming en bespreking } \\
\text { uitkomsten controle }\end{array}$ \\
\hline $\begin{array}{l}\text { Nederlandse Corporate Governance } \\
\text { Code - aansturing van de externe } \\
\text { accountant }\end{array}$ & $\begin{array}{l}\text { De auditcommissie overlegt zo vaak als zij dit noodzakelijk acht, doch ten minste } \\
\text { eenmaal per jaar, buiten aanwezigheid van het bestuur met de externe accountant } \\
\text { (1.7.4). }\end{array}$ & $\begin{array}{l}\text { Kennisneming en bespreking } \\
\text { uitkomsten controle }\end{array}$ \\
\hline \multirow[t]{2}{*}{ Besluit instelling auditcommissie } & \multirow{2}{*}{$\begin{array}{l}\text { Het in kennis stellen van het bestuur of de } \mathrm{RvC} \text { van de rechtspersoon van het } \\
\text { resultaat van de wettelijke controle, waarbij wordt toegelicht op welke wijze } \\
\text { de wettelijke controle heeft bijgedragen aan de integriteit van de financiële } \\
\text { verslaggeving en welke rol de auditcommissie in dat proces heeft gespeeld. }\end{array}$} & $\begin{array}{l}\text { - Kennisneming en opvolging } \\
\text { tussentijdse bevindingen }\end{array}$ \\
\hline & & $\begin{array}{l}\text { - Kennisneming en bespreking } \\
\text { uitkomsten controle }\end{array}$ \\
\hline \multirow{2}{*}{$\begin{array}{l}\text { Nederlandse Corporate Governance } \\
\text { Code - aansturing van de externe } \\
\text { accountant }\end{array}$} & \multirow{2}{*}{$\begin{array}{l}\text { De voorzitter van de auditcommissie is aanspreekpunt voor de externe accountant } \\
\text { wanneer hij bij de uitvoering van zijn opdracht een misstand of onregelmatigheid } \\
\text { constateert of vermoedt (best practice bepaling } 2.6 .3 \text { ). }\end{array}$} & $\begin{array}{l}\text { Kennisneming en opvolging } \\
\text { tussentijdse bevindingen }\end{array}$ \\
\hline & & $\begin{array}{l}\text { Kennisneming en bespreking } \\
\text { uitkomsten controle }\end{array}$ \\
\hline
\end{tabular}

